\title{
Perforation index assessment of cowpea seeds against cowpea bruchid, Callosobruchus maculatus (Fabricius) [Coleoptera: Chrysomelidae], infestation using Piper guineense
}

Kayode David Ileke ${ }^{1 *}$ (D) Jacobs Mobolade Adesina ${ }^{2,3}$, Luke Chinaru Nwosu ${ }^{4}$ and Abimbola Olagunju ${ }^{5}$

\begin{abstract}
Background: Powders and extracts of Piper guineense seeds and leaves were assessed for insecticidal activities against Callosobruchus maculatus in the laboratory at temperature and relative humidity of $29.6{ }^{\circ} \mathrm{C}$ and $75.9 \%$, respectively. Bioactive compounds in $P$. guineense leaves and seeds were also investigated. The powders were tested at rates 1.0, 2.0 and $4.0 \mathrm{~g} / 20 \mathrm{~g}$ cowpea seeds while extracts were tested at 1.0, 2.0 and 3.0\%.

Results: Results of contact toxicity assay of the seed powder caused $100 \%$ adult mortality at $96 \mathrm{~h}$ post-treatment period whereas leaf powder evoked $90 \%$ adult mortality within the same period at concentration of $1.0 \mathrm{~g} / 20 \mathrm{~g}$ cowpea seeds. Low adult emergence was observed on cowpea seeds treated with $1 \mathrm{~g}$ of seed powder with percentage adult emergence of $10.0 \%$ and inhibition rate (IR) of $97.5 \%$. Beetle Perforation Index (BPI) obtained from treated cowpea seeds was significantly different $(P<0.05)$ from BPI of untreated seeds. Extracts of $P$. guineense seed were more toxic than seed powder. Piper guineense seed extract caused $87.5 \%$ adult mortality of $C$. maculatus while leaf extract caused $70.0 \%$ adult mortality within $24 \mathrm{~h}$ of infestation at concentration of $1 \%$. Progeny development of C. maculatus was completely inhibited in cowpea treated with $2 \%$ and $3 \%$ leaf and seed extracts of $P$. guineense. $\beta$ Pinene was the most abundant active compound in P. guineense seed (55.6\%) and leaf (48.4\%). $\beta$-Phellandrene occurred $38.2 \%$ in seeds while Ocimene had the least value of $0.2 \%$ in seed and $0.5 \%$ in leaf.

Conclusion: The study showed that $P$. guineense seed powder and extracts were more effective than leaf powder and extract. Utilization of plant products as alternative to synthetic insecticides in protecting cowpea seeds against C. maculatus should be encouraged for enhanced food safety and security. Piper guineense is used as spice and medicine and interestingly safe for human use.
\end{abstract}

Keywords: Seeds, Insecticidal activities, Leaves, Bioactive compounds, Adult mortality, $\beta$-Pinene

\footnotetext{
* Correspondence: kdileke@futa.edu.ng; kayodeileke@yahoo.com ${ }^{1}$ Applied Entomology Unit, Department of Biology, School of Science, Federal University of Technology, PMB 704, Akure, Ondo State, Nigeria Full list of author information is available at the end of the article
}

\section{Springer Open}

(- The Author(s). 2020 Open Access This article is licensed under a Creative Commons Attribution 4.0 International License, which permits use, sharing, adaptation, distribution and reproduction in any medium or format, as long as you give appropriate credit to the original author(s) and the source, provide a link to the Creative Commons licence, and indicate if changes were made. The images or other third party material in this article are included in the article's Creative Commons licence, unless indicated otherwise in a credit line to the material. If material is not included in the article's Creative Commons licence and your intended use is not permitted by statutory regulation or exceeds the permitted use, you will need to obtain permission directly from the copyright holder. To view a copy of this licence, visit http://creativecommons.org/licenses/by/4.0/. 


\section{Background}

There is widespread deficiency in protein and other valuable nutrients in developing countries with bad consequences on the growth and development of children. Cowpea, Vigna unguiculata (Walp), seed is palatable and has high content of protein, vitamins and minerals (Nwosu, 2019). The cultivation and consumption of cowpea seeds should be encouraged because its consumption has become necessary with increasing emphasis on plant-based diet (Larochelle, Katungi and Cheng, 2016). For food security, economic and agronomic reasons, cowpea seeds must be stored after harvest and unfortunately in storage, the product is greatly damaged by Callosobruchus maculatus (Fab.) (Coleoptera: Bruchidae) insect pest (Casswell, 1981). Prolonged storage of cowpea seeds, particularly at small-scale farming and household levels, is limited due to infestation by C. maculatus and this usually culminates in loss in both quality and quantity of the product (Ileke, Odeyemi and Ashamo, 2013). Qualitative and quantitative depletions adversely affect available dietary protein level, market value and specimens for planting during next cropping season, and these are obstacles to achieving food security in many developing countries (IITA, 1995; Rouanet, 1992). The control of C. maculatus has relied on the use of synthetic insecticide, which unfortunately has caused problems such as development of resistance, pest resurgence, food poisoning and environmental contamination (Idoko and Adesina, 2012). The ecological and health problems associated with use of chemical insecticides justify the search for alternative methods of controlling C. maculatus such as the use of plant materials which are unquestionably safer.

In Nigeria and many other tropical and subtropical countries, there is an array of medicinal plants which could play a fundamental role in pest management (Oparaeke and Bunmi, 2006). A number of plants used locally for medicinal purposes have demonstrated potential for insect control (Arannilewa, Ekrakene and Akinneye, 2006). These are part of the motivation for our interest in plant materials.

Piper guineense (Piperaceae) is a West African species of Piper, also branded as West African pepper indigenous to Central and Western Africa topical regions and semicultivated in Nigeria where the plant leaves are used for flavouring (culinary uses) purposes. Medicinal uses, cosmetic (Dalziel, 1955) and insecticidal potential of P. guineense seeds had been reported (Fasakin and Aberejo, 2002; Idoko \& Adesina, 2012). This work therefore is aimed at determining the action of leaf and seed powder products of $P$. guineense in suppressing $C$. maculatus infestation on stored cowpea. Bioactive compounds in $P$. guineense leaves and seeds were also investigated and this is very important in holistic investigations.

\section{Methods}

\section{Experimental location}

This study was conducted at mean temperature and relative humidity of $29.6{ }^{\circ} \mathrm{C}$ and $75.9 \%$, respectively in the Research Laboratory of Animal and Environmental Biology Department, Adekunle Ajasin University, Akungba Akoko (AAUA), Ondo State, Nigeria, and at Insect Chemical Ecology Laboratory, Institute of Bioresources and Sustainable Development, Takyelpat, Imphal, 795001, Manipur, India.

\section{Insect culture}

The initial insects used to establish a laboratory colony of $C$. maculatus was obtained from a batch of infested "Oloyin" (Susceptible variety) local cowpea cultivar collected from Ibaka market, Akungba Akoko, Ondo State, Nigeria. The insect culture was by the methods reported by Odeyemi and Daramola (2000) and Ileke et al. (2013). One hundred pairs (10 males to 10 females) of newly emerged adults of Callosobruchus maculatus were introduced into the $500 \mathrm{~g}$ of cowpea seeds in kilner jar. The kilner jar was then covered with muslin cloth held tightly with rubber band to allow easy flow of air and at the same time prevent the insects from escaping. The insect culture was kept in the laboratory for 1 month (30 days) to allow the insects to oviposit and multiply. The new adults that emerged were subsequently reared on clean uninfested Ife brown variety in the laboratory and serve as the stock culture of the insects used throughout the experiment. The insects were reared under a laboratory condition of $28 \pm 2{ }^{\circ} \mathrm{C}$ temperature and $75 \pm 5 \%$ relative humidity.

\section{Plant collection and preparation}

Leaves and seeds of $P$. guineense were obtained in fresh form from the herbal stall of Ibaka market, Akungba Akoko, Ondo State, Nigeria, and authenticated at the Plant Science and Biotechnology Department, AAUA, Ondo State, Nigeria. The plant materials were rinsed in clean water to remove dirt and other impurities, cut into smaller pieces, air dried in a well-ventilated laboratory and milled into very fine powder using an electric blender. The resulting powders were then kept in air tight containers and labelled separately inside the refrigerator at $4{ }^{\circ} \mathrm{C}$ to maintain their quality before application.

About $150 \mathrm{~g}$ of $P$. guineense leaves powder was soaked in an extraction bottle containing absolute methanol for $72 \mathrm{~h}$ and the mixture was stirred occasionally with a glass rod. The mixture was stirred occasionally using a glass rod and in order to ensure uniformity in extraction. The extraction process was carried out using a double layer of Whatman No. 1 filter papers. The mixture of the solvent and the extract was separated using a rotary 
evaporator at 30 to $40{ }^{\circ} \mathrm{C}$ with rotary speed of 3 to 6 rpm for $8 \mathrm{~h}$ (Udo, Ekanem and Inyang, 2011). The resulting extracts were then air dried in order to remove traces of the solvent. The same procedure was adopted for the extraction of other plant product ( $P$. guineense seeds). The crude extracts were kept in an amber bottle labelled and preserved in the refrigerator till further use. From this stock solution, $1 \%$ concentration was prepared by diluting $0.1 \mathrm{ml}$ of extract in $9.9 \mathrm{ml}$ of solvent; $2 \%$ concentration was prepared by diluting $0.2 \mathrm{ml}$ of extract in $9.8 \mathrm{ml}$ of solvent and $3 \%$ concentration was prepared by diluting $0.3 \mathrm{ml}$ of extract in $9.7 \mathrm{ml}$ of solvent (Ashamo and Akinnawonu, 2012).

\section{Collection of cowpea seeds}

The experimental cowpea seeds (Ife brown variety) were gotten from a newly stocked seeds (without insecticide treatment) in a store at Ibaka market, Akungba Akoko, Ondo State, Nigeria. The seeds were properly sieved, handpicked and disinfested by keeping at $-5{ }^{\circ} \mathrm{C}$ for 7 days to kill all hidden infestations (if any). All the life stages, particularly the eggs, are very sensitive to cold (Koehler, 2003). The disinfested cowpea seeds were later air dried in the laboratory to prevent mouldiness (Adedire, Obembe, Akinkurolele and Oduleye, 2011) before they were stored in plastic containers with tight lids until ready for use.

\section{Toxicity of $P$. guineense leaves and seeds powders to $C$. maculatus}

Fine powders of $P$. guineense leaves and seeds were admixed with cowpea seeds at the rate of $1 \mathrm{~g}, 2 \mathrm{~g}$ and 4 $\mathrm{g} / 20 \mathrm{~g}$ of cowpea seeds in $250 \mathrm{ml}$ plastic containers. Ten copulating pairs of $C$. maculatus ( $0-3$ days old) were introduced into the plastic containers and untreated cowpea seeds replicated four times. The sex of the beetle was determined according to procedures outlined by (Odeyemi \& Daramola, 2000). Mortality of adult $C$. maculatus was evaluated daily for 4 days. Sharp pin was used to probe whether the insect was alive or dead. At $96 \mathrm{~h}$ after infestation, all insects were removed from treated and untreated seeds. Percentage adult mortality was corrected using Abbott formula (Abbott, 1925).

$$
\% \text { Adult Mortality }=\frac{\text { Number of dead adults }}{\text { Number of adults introduced }} \times \frac{100}{1}
$$

Oviposition by adult cowpea bruchid on cowpea seeds were recorded before returning the seeds to their respective containers for the emergence of first filial generation. Emerged adult insects were expressed in percentage using standard method as follows:
$\%$ Adult emergence $=\frac{\text { Total number of adult emergence }}{\text { Total number of eggs laid }} \times \frac{100}{1}$

Progeny inhibition rate (IR) was also calculated using the method described by Tapondjoun, Alder, Bonda and Fontem (2002).

$$
\% \mathrm{IR}=\frac{C_{n}-T_{n}}{C_{n}} \times \frac{100}{1}
$$

where

$C_{n}=$ number of emerged insects in the control; and

$T_{n}=$ number of emerged insects in the treated.

Reduction in weight of the cowpea seeds was assessed as follows:

$$
\% \text { Weight loss }=\frac{\text { Initial weight }- \text { Final weight }}{\text { Initial weight }} \times \frac{100}{1}
$$

Damaged seeds were evaluated by expressing wholesome seeds and bored seeds by adult insect in percentages as follows:

$$
\% \text { Seed damage }=\frac{\text { Number of seeds damage }}{\text { Total number of seeds }} \times \frac{100}{1}
$$

Beetle Perforation Index (BPI) was also evaluated for the analysis of damage.

$$
B P I=\frac{\% \text { treated paddy perforated }}{\text { \%control paddy perforated }} \times 100
$$

BPI value that exceeded 50 will be regarded as enhancement of damaged by cowpea bruchid or negative protectant (Fatope, Mann and Takeda, 1995).

\section{Toxicity of $P$. guineense leaves and seeds extracts to $C$. maculatus}

The assay follows the same procedure as described for contact toxicity of $P$. guineense powder above except that $1 \%, 2 \%$ and $3 \%$ concentration of each extract of leaves and seeds of the plant material was mixed separately with $20 \mathrm{~g}$ of uninfested cowpea seeds in $250 \mathrm{ml}$ plastic containers and this was achieved using a glass rod. Agitation for $10 \mathrm{~min}$ then followed immediately to ensure uniform coating. The containers were left open for 30 min to allow solvent traces evaporate. Control experiment was also set up.

\section{Phytochemical screening of $P$. guineense}

Qualitative phytochemical screening were carried out on the methanol extracts of $P$. guineense seeds and leaves to identify various phytochemical constituents such as alkaloids, tannins, anthraquinones, phlobatannin, cardiac glycosides, saponins and flavonoids present in the plant materials using standard laboratory protocols (Harborne, 
1973; Sofowora, 1993; Trease and Evans, 1998; Prashant, Bimlesh, Mandeep, Gurpreet and Harleen, 2011).

\section{Gas chromatography-mass spectrometry of $P$. guineense} The GC-MS an analysis of $P$. guineense seed and leaves extracts were performed using a Hewlett-Packard apparatus equipped with an HP-1 fused silica column ( $30 \mathrm{~m} \times$ $0.20 \mathrm{~mm}$, film thickness $0.25 \mu \mathrm{m}$ ) and interfaced with a quadrupole detector (Model 5970) operated in electron impact mode. The oven temperature was automated from 70 to $200^{\circ} \mathrm{C}$ at $10^{\circ} \mathrm{C} / \mathrm{min}$; injector temperature was $220^{\circ} \mathrm{C}$. Helium was used as carrier gas at a flow rate of $0.6 \mathrm{~mL} / \mathrm{min}$; the mass spectrometer was operated at $70 \mathrm{eV}$. Constituent identification was apportioned on the basis of comparison of their retention indices and mass spectra with those given in the Wiley $275 \mathrm{~L}$ mass spectral library literature (Adams, 2007).

\section{Statistical analysis}

Data were subjected to analysis of variance (ANOVA) and significant treatment means were separated using Tukey's test. The ANOVA was performed with SPSS 25.0 software (SPSS, 2017).

\section{Results}

\section{Mortality of adult C. maculatus in cowpea seeds treated} with $P$. guineense powders

The effectiveness of the $P$. guineense powders on the survival of $C$. maculatus at different hours after treatment is presented in Table 1 . There was a significant difference $(P<0.05)$ in insect adult mortality amongst the treatments. Mortality of insect increased gradually with time of contact with $P$. guineense seed powder causing $100 \%$ mortality within $96 \mathrm{~h}$ of exposure, whereas the leaf powder evoked $90 \%$ mortality within the same period at concentration $1 \mathrm{~g} / 20 \mathrm{~g}$ of cowpea seeds. Mortality of $C$. maculatus varied with plant parts, dosage and period of exposure. The highest mortality of $95 \%$ was obtained at $3 \mathrm{~g} / 20 \mathrm{~g}$ of cowpea seeds with the seed powder within
$24 \mathrm{~h}$ of exposure, while the leaf powder caused $82.5 \%$ mortality of adult insect within $24 \mathrm{~h}$ of exposure.

\section{Effect of $P$. guineense powders on C. maculatus emergence}

Plant powder reduced fecundity of adult C. maculatus (Table 2). The amount of eggs laid on treated cowpea seeds by $C$. maculatus was significantly $(P<0.05)$ lower than amount of oviposition on untreated cowpea seeds. There was no significant difference $(P>0.05)$ in the mean number of oviposition cowpea seeds treated with $P$. guineense seed and leaf powders, but were significantly different when compared to untreated seed. The $\%$ adult emergence in the control experiment (64\%) was significantly higher $(P<0.05)$ compared to cowpea seeds treated $P$. guineense leaf powder $(20 \%)$ at rate $1 \mathrm{~g} / 20 \mathrm{~g}$ of cowpea seeds. However, the lowest number of adult emergence was observed on cowpea seeds treated with seed powder at rate $1 \mathrm{~g} / 20 \mathrm{~g}$ of cowpea seeds with percentage adult emergence of $0.0 \%$ and inhibition rate (IR) of $100 \%$. Similarly, P. guineense leaf powder completely inhibited adult emergence at rate $3 \mathrm{~g} / 20 \mathrm{~g}$ of cowpea seeds.

\section{Beetle perforation index caused by $C$. maculatus in cowpea seeds treated with $P$. guineense powders} Piper guineense seed powder completely protected cowpea seeds from being damaged by $C$. maculatus concentrations $2 \mathrm{~g}$ and $3 \mathrm{~g} / 20 \mathrm{~g}$ (Table 3). There was neither seed damage nor weight loss recorded in the treated cowpea seeds. Meanwhile, leaf powder significantly suppressed infestation as manifested in percentage seed damage and weight loss compared to untreated cowpea seeds. Beetle Perforation Index (BPI) was zero in cowpea seed treated with seed powder at rate $2 \mathrm{~g}$ and $3 \mathrm{~g} / 20 \mathrm{~g}$ of cowpea seeds, leaf powder recorded $10 \%$ and $2.5 \%$ at rate $1 \mathrm{~g}$ and $2 \mathrm{~g} / 20 \mathrm{~g}$ of cowpea seeds, while untreated seed recorded $>50.00 \%$ perforation index. However, the BPI obtained from treated cowpea seeds was

Table 1 Dose-response table of C. maculatus adults treated with P. guineense powders

\begin{tabular}{|c|c|c|c|c|c|}
\hline \multirow{2}{*}{$\begin{array}{l}P . \\
\text { guineense } \\
\text { powders }\end{array}$} & \multirow{2}{*}{$\begin{array}{l}\text { Conc. } \\
\text { (g) }\end{array}$} & \multicolumn{4}{|c|}{$\%$ mortality \pm SE mean } \\
\hline & & $24 \mathrm{~h}$ & $48 \mathrm{~h}$ & $72 \mathrm{~h}$ & $96 \mathrm{~h}$ \\
\hline$\overline{\text { Leaf }}$ & 1.0 & $50.00 \pm 3.25^{b}$ & $77.50 \pm 3.25^{b}$ & $82.50 \pm 3.25^{b}$ & $90.00 \pm 3.04^{b}$ \\
\hline Seeds & & $70.00 \pm 3.25^{c}$ & $82.50 \pm 3.75^{b}$ & $95.00 \pm 3.50^{c}$ & $100.00 \pm 0.00^{b}$ \\
\hline Leaf & 2.0 & $75.00 \pm 3.50^{c d}$ & $80.00 \pm 3.04^{b}$ & $90.00 \pm 2.04^{c}$ & $100.00 \pm 0.00^{b}$ \\
\hline Seeds & & $87.50 \pm 3.25^{\mathrm{ef}}$ & $95.00 \pm 3.50^{c}$ & $100.00 \pm 0.00^{c}$ & $100.00 \pm 0.00^{b}$ \\
\hline Leaf & 3.0 & $82.50 \pm 3.75^{d}$ & $90.00 \pm 3.04^{c}$ & $100.00 \pm 0.00^{c}$ & $100.00 \pm 0.00^{b}$ \\
\hline Seeds & & $95.00 \pm 3.50^{f}$ & $100.00 \pm 0.00^{c}$ & $100.00 \pm 0.00^{c}$ & $100.00 \pm 0.00^{\mathrm{b}}$ \\
\hline Untreated & 0.0 & $0.00 \pm 0.00^{a}$ & $0.00 \pm 0.00^{\mathrm{a}}$ & $0.00 \pm 0.00^{a}$ & $0.00 \pm 0.00^{a}$ \\
\hline
\end{tabular}

Each value is a mean \pm standard error of four replicates. Means within the same column followed by the same letter are not significantly different at $P>0.05$ using Tukey's test 
Table 2 Progeny development of C. maculatus in cowpea seeds protected with P. guineense powders

\begin{tabular}{lllll}
\hline $\boldsymbol{P}$. guineense powders & Conc. $(\mathbf{g})$ & Mean number of eggs laid & \% adult emergence & \%IR \\
\hline Leaf & 1 & $20.00 \pm 2.04^{\mathrm{b}}$ & $20.00 \pm 2.04^{\mathrm{c}}$ & $90.00 \pm 3.04^{\mathrm{b}}$ \\
Seed & & $10.00 \pm 1.04^{\mathrm{ab}}$ & $10.00 \pm 1.04^{\mathrm{bc}}$ & $97.50 \pm 2.50^{\mathrm{b}}$ \\
Leaf & 2 & $12.50 \pm 1.75^{\mathrm{ab}}$ & $8.00 \pm 0.04^{\mathrm{b}}$ & $97.00 \pm 2.50^{\mathrm{b}}$ \\
Seed & & $7.50 \pm 0.25^{\mathrm{a}}$ & $0.00 \pm 0.00^{\mathrm{a}}$ & $100.00 \pm 0.00^{\mathrm{b}}$ \\
Leaf & 3 & $7.50 \pm 0.25^{\mathrm{a}}$ & $0.00 \pm 0.00^{\mathrm{a}}$ & $100.00 \pm 0.00^{\mathrm{b}}$ \\
Seed & & $5.00 \pm 0.04^{\mathrm{a}}$ & $0.00 \pm 0.00^{\mathrm{a}}$ & $100.00 \pm 0.00^{\mathrm{b}}$ \\
Untreated & 0.0 & $62.50 \pm 3.75^{\mathrm{a}}$ & $64.00 \pm 3.22^{\mathrm{d}}$ & $0.00 \pm 0.00^{\mathrm{a}}$ \\
\hline
\end{tabular}

Each value is a mean \pm standard error of four replicates. Means within the same column followed by the same letter (s) are not significantly different at $P>0.05$ using Tukey's test

significantly different from BPI of the untreated. In the untreated cowpea seeds, $42.50 \%$ damage occurred as revealed by adult emergent holes of the bruchid. As a result of the feeding activity of $C$. maculatus larvae on the cowpea seeds, the weight of the untreated cowpea seeds was significantly $(P<0.05)$ reduced compared with the treated seeds.

\section{Mortality of adult C. maculatus in cowpea seeds treated} with $P$. guineense extracts

Piper guineense seed extract caused 100\% adult mortality of C. maculatus while leaves extract caused $92.5 \%$ adult mortality within $24 \mathrm{~h}$ of infestation at concentration $1 \%$ / $20 \mathrm{~g}$ of cowpea seeds. The adult mortality observed in the study with cowpea seeds treated with leaves and seeds extracts increased with the duration of exposure (Table 4) and the mortality recorded was significantly higher compared to solvent treated (+ve control) and untreated (-ve control) seeds. The untreated seeds exerted no adult mortality effects on the adult beetles over the duration of exposure.

Effect of $P$. guineense extracts on $C$. maculatus emergence The plant extract significantly reduced the number of eggs laid by C. maculatus compared with untreated cowpea seeds. Cowpea bruchid laid the lowest mean number of eggs (0.0 eggs) on cowpea treated with seed extract followed by 1.00 eggs laid on cowpea treated with leaves extract at concentration $3 \% / 20 \mathrm{~g}$ of cowpea seeds (Table 5). Callosobruchus maculatus adult emergence at concentrations $2 \%$ and $3 \% / 20 \mathrm{~g}$ of cowpea seeds was completely inhibited in cowpea treated with both leaves and seed extracts of $P$. guineense with inhibition rate (IR) of $100 \%$ compared to control that recorded $64 \%$ adult emergence. Treating cowpea seeds with methanol did not prevent progeny emergence from seeds.

\section{Beetle perforation index caused by $C$. maculatus in cowpea seeds treated with $P$. guineense extracts}

The $P$. guineense extracts completely prevented infestation and suppressed damage of the treated cowpea seed at concentrations $2 \%$ and $3 \% / 20 \mathrm{~g}$ of cowpea seeds (Table 6). There was neither seed damage nor weight loss recorded in the cowpea seeds treated with seed extract at rate $1 \%, 2 \%$ and $3 \%$ as well as leaf extract at concentrations of $2 \%$ and $3 \% / 20 \mathrm{~g}$ of cowpea seeds. Same trend was equally observed for Beetle Perforation Index compared to untreated seed that suffered greater infestation and damage. Beetle Perforation Index (BPI) value lower than 50 is an index of positive protectant effect while BPI greater than 50 is an index of negative protectability. In the untreated cowpea seeds, $42.50 \%$ damage occurred and $52.50 \%$ weight loss; the weight of

Table 3 Perforation Index caused by C. maculatus in cowpea seeds treated with $P$. guineense powders

\begin{tabular}{lllllll}
\hline $\begin{array}{l}P . \text { guineense } \\
\text { powders }\end{array}$ & $\begin{array}{l}\text { Conc. } \\
(\mathbf{g})\end{array}$ & $\begin{array}{l}\text { Total no of } \\
\text { seeds }\end{array}$ & $\begin{array}{l}\text { Number of damaged } \\
\text { seeds }\end{array}$ & $\begin{array}{l}\text { \% seed } \\
\text { damaged }\end{array}$ & $\begin{array}{l}\text { \% weight } \\
\text { loss }\end{array}$ & $\begin{array}{l}\text { *Beetle Perforation Index } \\
\text { (BPI) }\end{array}$ \\
\hline Leaf & 1.0 & 95.25 & 4.00 & $4.50 \pm 0.07^{\mathrm{ab}}$ & $10.00 \pm 1.04^{\mathrm{a}}$ & $10.00 \pm 1.04^{\mathrm{a}}$ \\
Seeds & & 94.75 & 1.00 & $1.05 \pm 0.02^{\mathrm{ab}}$ & $5.00 \pm 0.02^{\mathrm{a}}$ & $2.50 \pm 0.02^{\mathrm{a}}$ \\
Leaf & 2.0 & 94.50 & 1.00 & $1.05 \pm 0.01^{\mathrm{ab}}$ & $5.00 \pm 0.02^{\mathrm{a}}$ & $2.50 \pm 0.02^{\mathrm{a}}$ \\
Seeds & & 95.25 & 0.00 & $0.00 \pm 0.00^{\mathrm{a}}$ & $0.00 \pm 0.00^{\mathrm{a}}$ & $0.00 \pm 0.00^{\mathrm{a}}$ \\
Leaf & 3.0 & 94.00 & 0.00 & $0.00 \pm 0.00^{\mathrm{a}}$ & $0.00 \pm 0.00^{\mathrm{a}}$ & $0.00 \pm 0.00^{\mathrm{a}}$ \\
Seeds & & 95.50 & 0.00 & $0.00 \pm 0.00^{\mathrm{a}}$ & $0.00 \pm 0.00^{\mathrm{a}}$ & $0.00 \pm 0.00^{\mathrm{a}}$ \\
Untreated & 0.0 & 95.25 & 40.00 & $42.50 \pm 3.75^{\mathrm{a}}$ & $75.00 \pm 3.20^{\mathrm{a}}$ & $>50.00 \pm 0.00$ \\
\hline
\end{tabular}

Each value is a mean \pm standard error of four replicates. Means within the same column followed by the same letter are not significantly different at $P>0.05$ using Tukey's test

* - Perforation Index 
Table 4 Concentration-response table of C. maculatus adults treated with $P$. guineense extracts

\begin{tabular}{|c|c|c|c|c|c|}
\hline \multirow[t]{2}{*}{ P. guineense extracts } & \multirow{2}{*}{$\begin{array}{l}\text { Conc. } \\
(\%)\end{array}$} & \multicolumn{4}{|c|}{$\%$ mortality \pm SE mean } \\
\hline & & $24 \mathrm{~h}$ & $48 \mathrm{~h}$ & $72 \mathrm{~h}$ & $96 \mathrm{~h}$ \\
\hline P. guineense leaf & 1 & $70.00 \pm 3.04^{c}$ & $82.50 \pm 3.75^{c}$ & $92.50 \pm 3.75^{b}$ & $100.00 \pm 0.00^{b}$ \\
\hline P. guineense seeds & & $87.50 \pm 3.25^{\mathrm{de}}$ & $92.50 \pm 3.75^{\mathrm{cd}}$ & $100.00 \pm 0.00^{b}$ & $100.00 \pm 0.00^{b}$ \\
\hline Methanol (+ve control) & & $0.00 \pm 0.00^{\mathrm{a}}$ & $5.00 \pm 0.04^{b}$ & $7.50 \pm 0.25^{\mathrm{a}}$ & $10.00 \pm 1.04^{b}$ \\
\hline P. guineense leaf & 2 & $80.00 \pm 3.04^{c d}$ & $90.00 \pm 3.04^{c d}$ & $100.00 \pm 0.00^{c}$ & $100.00 \pm 0.00^{b}$ \\
\hline P. guineense seeds & & $92.50 \pm 3.75^{\mathrm{ef}}$ & $100.00 \pm 0.00^{d}$ & $100.00 \pm 0.00^{c}$ & $100.00 \pm 0.00^{b}$ \\
\hline Methanol (+ve control) & & $2.50 \pm 0.02^{\mathrm{a}}$ & $7.50 \pm 0.25^{b}$ & $10.00 \pm 1.04^{a}$ & $12.50 \pm 1.75^{b}$ \\
\hline P. guineense leaf & 3 & $92.50 \pm 3.75^{\mathrm{ef}}$ & $100.00 \pm 0.00^{d}$ & $100.00 \pm 0.00^{c}$ & $100.00 \pm 0.00^{b}$ \\
\hline P. guineense seeds & & $100.00 \pm 0.00^{f}$ & $100.00 \pm 0.00^{d}$ & $100.00 \pm 0.00^{c}$ & $100.00 \pm 0.00^{\mathrm{b}}$ \\
\hline Methanol (+ve control) & & $5.00 \pm 0.04^{b}$ & $10.00 \pm 1.04^{b}$ & $12.50 \pm 1.75^{\mathrm{a}}$ & $17.50 \pm 1.25^{b}$ \\
\hline Untreated (-ve control) & 0.0 & $0.00 \pm 0.00^{\mathrm{a}}$ & $0.00 \pm 0.00^{\mathrm{a}}$ & $0.00 \pm 0.00^{\mathrm{a}}$ & $0.00 \pm 0.00^{\mathrm{a}}$ \\
\hline
\end{tabular}

Each value is a mean \pm standard error of four replicates. Means within the same column followed by the same letter are not significantly different at $P>0.05$ using Tukey's test

untreated cowpea seeds was significantly $(P<0.05)$ reduced compared with the treated seeds. The BPI values obtained on seeds treated with $1 \%, 2 \%$ and $3 \%$ methanol were significantly higher than $50 \%$ compared with seeds treated with plant extracts.

\section{Phytochemical screening of Piper guineense}

The results of the qualitative phytochemical constituents of both extracts, as shown in Table 7, revealed the presence of alkaloids, saponins, tannins, flavonoids and cardiac glycosides, while phlobatannins and anthraquinones were not present in both leaves and seeds of the plants.

\section{Bioactive compounds $P$. guineense leaves and seeds}

The major bioactive compounds identified by GC-MS analysis from the leaves and seeds of $P$. guineense are shown in Table 8 . The result shows that both seeds and leaves contain the same bioactive compounds at varying percentages. $\beta$-Pinene was the most abundant $55.6 \%$ in seeds and $48.4 \%$ in leaves of $P$. guineense. This was followed by $\beta$-Phellandrene which occurred $38.2 \%$ in seeds while the least was Ocimene with a value of $0.2 \%$ in seeds and $0.5 \%$ in leaves.

\section{Discussion}

Plants are rich source of bioactive chemical compounds with insecticidal properties (Rajkumar and Jebanesan, 2004). The activity of plant products is ascribed to the complex mixture of active compounds (Sukhthankar, Kumar, Godinho and Kumar, 2014). The potential of powdered and methanol extract of $P$. guineense leaves and seeds in causing acute toxicity, preventing oviposition and perforation to cowpea seeds by $C$. maculatus has been demonstrated in this study and results obtained conformed with the conclusions of Su (1977), Ivbijaro and Agbaje (1986) and Ogunwolu, Igoři and Longs

Table 5 Progeny (F1) development of C. maculatus in cowpea seeds that were protected with $P$. guineense seed powders

\begin{tabular}{|c|c|c|c|c|}
\hline P. guineense powders & Conc. (g) & Mean number of eggs laid & $\%$ adult emergence & $\%$ IR \\
\hline P. guineense leaf & 1 & $10.00 \pm 1.04^{b}$ & $10.00 \pm 1.04^{b}$ & $97.50 \pm 2.50$ \\
\hline P. guineense seeds & & $7.50 \pm 0.25^{b}$ & $0.00 \pm 0.00^{\mathrm{a}}$ & $100.00 \pm 0.00^{c}$ \\
\hline Methanol (+ve control) & & $47.50 \pm 2.25^{c}$ & $63.50 \pm 3.70^{c}$ & $25.00 \pm 2.20^{b}$ \\
\hline P. guineense leaf & 2 & $5.00 \pm 0.04^{b}$ & $0.00 \pm 0.00^{\mathrm{a}}$ & $100.00 \pm 0.00^{c}$ \\
\hline P. guineense seeds & & $2.50 \pm 0.02^{\mathrm{ab}}$ & $0.00 \pm 0.00^{\mathrm{a}}$ & $100.00 \pm 0.00^{c}$ \\
\hline Methanol (+ve control) & & $45.00 \pm 2.20^{c}$ & $60.00 \pm 3.20^{c}$ & $30.00 \pm 2.04^{b}$ \\
\hline$P$. guineense leaf & 3 & $1.00 \pm 0.01^{\mathrm{ab}}$ & $0.00 \pm 0.00^{\mathrm{a}}$ & $100.00 \pm 0.00^{c}$ \\
\hline P. guineense seeds & & $0.00 \pm 0.00^{\mathrm{a}}$ & $0.00 \pm 0.00^{\mathrm{a}}$ & $100.00 \pm 0.00^{c}$ \\
\hline Methanol (+ve control) & & $42.50 \pm 2.04^{c}$ & $57.50 \pm 3.50^{c}$ & $35.00 \pm 3.20^{b}$ \\
\hline Untreated (-ve control) & 0 & $62.50 \pm 3.75^{d}$ & $64.00 \pm 3.22^{c}$ & $0.00 \pm 0.00^{\mathrm{a}}$ \\
\hline
\end{tabular}

Each value is a mean \pm standard error of four replicates. Means within the same column followed by the same letter are not significantly different at $P>0.05$ using Tukey's test 
Table 6 Perforation Index caused by C. maculatus in cowpea seeds treated with P. guineense powders

\begin{tabular}{|c|c|c|c|c|c|c|}
\hline $\begin{array}{l}P \text {. guineense } \\
\text { extracts }\end{array}$ & $\begin{array}{l}\text { Conc. } \\
(\%)\end{array}$ & $\begin{array}{l}\text { Total no of } \\
\text { seeds }\end{array}$ & $\begin{array}{l}\text { Number of damaged } \\
\text { seeds }\end{array}$ & $\begin{array}{l}\text { \% seed } \\
\text { damaged }\end{array}$ & $\begin{array}{l}\% \text { weight } \\
\text { loss }\end{array}$ & $\begin{array}{l}\text { *Beetle Perforation Index } \\
\text { (BPI) }\end{array}$ \\
\hline P. guineense leaf & 1 & 93.50 & 1.00 & $2.50 \pm 0.02^{\mathrm{ab}}$ & $5.00 \pm 0.04^{b}$ & $5.50 \pm 0.05^{b}$ \\
\hline P. guineense seeds & & 95.25 & 0.00 & $0.00 \pm 0.00^{\mathrm{ab}}$ & $0.00 \pm 0.00^{\mathrm{a}}$ & $0.00 \pm 0.00^{\mathrm{a}}$ \\
\hline $\begin{array}{l}\text { Methanol (+ve } \\
\text { control) }\end{array}$ & & 92.00 & 0.00 & $32.50 \pm 2.25^{\mathrm{cd}}$ & $40.00 \pm 2.04^{c}$ & $75.00 \pm 3.04^{c}$ \\
\hline P. guineense leaf & 2 & 94.00 & 0.00 & $0.00 \pm 0.00^{\mathrm{a}}$ & $0.00 \pm 0.00^{\mathrm{a}}$ & $0.00 \pm 0.00^{\mathrm{a}}$ \\
\hline P. guineense seeds & & 94.02 & 0.00 & $0.00 \pm 0.00^{\mathrm{a}}$ & $0.00 \pm 0.00^{\mathrm{a}}$ & $0.00 \pm 0.00^{\mathrm{a}}$ \\
\hline $\begin{array}{l}\text { Methanol (+ve } \\
\text { control) }\end{array}$ & & 96.00 & 0.00 & $27.50 \pm 2.50^{c}$ & $37.50 \pm 2.50^{c}$ & $65.00 \pm 3.04^{c}$ \\
\hline P. guineense leaf & 3 & 95.00 & 0.00 & $0.00 \pm 0.00^{\mathrm{a}}$ & $0.00 \pm 0.00^{\mathrm{a}}$ & $0.00 \pm 0.00^{\mathrm{a}}$ \\
\hline P. guineense seeds & & 94.50 & 0.00 & $0.00 \pm 0.00^{\mathrm{a}}$ & $0.00 \pm 0.00^{\mathrm{a}}$ & $0.00 \pm 0.00^{\mathrm{a}}$ \\
\hline $\begin{array}{l}\text { Methanol (+ve } \\
\text { control) }\end{array}$ & & 93.00 & 0.00 & $25.00 \pm 2.20^{c}$ & $35.00 \pm 2.20^{c}$ & $60.00 \pm 3.04^{c}$ \\
\hline $\begin{array}{l}\text { Untreated (-ve } \\
\text { control) }\end{array}$ & 0.0 & 95.25 & 40.00 & $42.50 \pm 3.75^{d}$ & $52.50 \pm 3.20^{d}$ & $>50.00 \pm 0.00$ \\
\hline
\end{tabular}

Each value is a mean \pm standard error of four replicates. Means within the same column followed by the same letter are not significantly different at $P>0.05$ using Tukey's test

* - Perforation Index

(1988) who reported insecticidal activity of P. guineense extract and powdered products against Sitophilus oryzae and Callosobruchus maculatus, respectively.

The effectiveness of $P$. guineense on mortality of cowpea bruchid in this work is due to contact toxicity effect as a result of volatile constituent which may lead to respiratory impairment, which affects their metabolism and consequently other systems of the insect body (Islam et al., 2009; Ofuya and Dawodu, 2002). Ogunwolu et al. (1988) viewed that P. guineense powder can cause physical abrasion of the insect cuticle which can lead to loss of body fluid or blockage of spiracles resulting into suffocation of the insect. The significant insect mortality caused by the application of seeds powder and extracts may be ascribed to the presence of highly spicy alkaloidic secondary metabolites (Udo et al., 2011). This prevented locomotion, physical contact of adult beetles with seeds and triggered asphyxia, starvation of adult insect or unknown physiological changes activation (Adesina, Jose, Rajashekar and Afolabi, 2015).

The reduced oviposition and completely inhibited progeny development clearly indicated that $P$. guineense mechanism of action is by oviposition deterrence and toxicity to eggs (ovicidal). The suppression of oviposition by the insects in treated containers compared to untreated may be due to locomotion impediment; hence, the beetle was unable to move freely thereby affecting mating activities and sexual communication (Adesina, 2013; Ileke, 2014; Odeyemi \& Daramola, 2000) resulting in few number of eggs observed in this study. Zabri, Kabran, Kodjo and Trabi (2009) opined that the ability of pesticidal plant products to reduce the egg laying capability by female beetles may be ascribed to the occurrence of flavonoids (Ileke, 2014). The reduction in oviposition in the extract-treated seeds compared to powder may also be caused by an

Table 7 Phytochemicals in different extracts of $P$. guineense leaf and seed

\begin{tabular}{lllll}
\hline Phytochemicals & $\begin{array}{l}\text { Methanol extract of } P . \\
\text { guineense leaf }\end{array}$ & $\begin{array}{l}\text { Aqueous extract of } P . \\
\text { guineense leaf }\end{array}$ & $\begin{array}{l}\text { Methanol extract of } P . \\
\text { guineense seed }\end{array}$ & $\begin{array}{l}\text { Aqueous extract of } P . \\
\text { guineense seed }\end{array}$ \\
\hline Alkaloids & + & + & + & + \\
Saponins & + & + & + & + \\
Tannins & + & + & - & + \\
Phlobatannins & - & - & - & - \\
Anthraquinones & - & - & + & + \\
Flavonoids & + & + & + & + \\
Cardiac & + & + & & \\
glycosides & & &
\end{tabular}

- negative, + positive 
Table 8 Major bioactive chemical composition of $P$. guineense leaves and seeds extracts

\begin{tabular}{llll}
\hline Bioactive molecules & Retention time & Leaves (\%) & Seeds (\%) \\
\hline B-Phellandrene & 10.12 & 3.4 & 38.2 \\
a-Phellandrene & 10.12 & 4.5 & 7.2 \\
Limonene & 10.20 & 15.7 & 10.3 \\
Ocimene & 10.45 & 0.5 & 0.2 \\
Linalol & 10.90 & 1.5 & 4.6 \\
a-Pinene & 12.20 & 6.3 & 10.3 \\
Pyridine & 12.45 & 1.4 & 2.3 \\
B-Pinene & 12.70 & 48.4 & 55.6 \\
B-Myrcene & 13.26 & 1.4 & 2.5 \\
a-Cubebene & 13.52 & 3.0 & 1.0 \\
a-Copaene & 13.78 & 0.7 & 1.2 \\
a-Caryophellene & 14.19 & 4.1 & 17.6 \\
a-Curcumene & 14.80 & 1.2 & 1.0 \\
(E, Z) a-Foreseen & 15.21 & 3.9 & 1.9 \\
cis-a-Bisabolene & 15.00 & 1.0 & 0.6 \\
Eugenol & 19.89 & 1.3 & 3.7 \\
Piperanol & 20.39 & 3.2 & 7.9 \\
\hline
\end{tabular}

extract film on the seeds which makes it becomes unsuitable for oviposition (Adesina and Ofuya, 2015).

The experimental plant products significantly reduced adult emergence or progeny development in treated cowpea seeds. The reduction in adult emergence could be due to ovicidal or larvicidal effects of the plant products. The results from the study shows that few eggs were oviposited on cowpea seed treated with powder and extract of $P$. guineense seeds but with no adult emergence. Partial blastokinesis and abnormal breakage of extra embryonic membranes in the embryo can result into reduction in progeny development or emergence of teneral adult insect (Enslee and Riddiford, 1977). The ability of the evaluated plant materials to significantly suppress or inhibit adult emergence confirms the insecticidal activity of the plant species in reducing oviposition and adult emergence (Abdullahi and Muhammad, 2004). The significant inhibition of the progeny development of $C$. maculatus by the seed powder and extract of $P$. guineense could also probably be attributed to the presence of appreciable vapour pressure from which poison toxic amounts could be ingested picked by insects through the vapour phase (Lale, 2002). The pungent vapour of $P$. guineense might have diffused into seeds and ingested by the larval stages (moulting) of C. maculatus developing within the seed thus leading to reduced or complete inhibition of progeny emergence due to impaired physiological and biochemical process associated with post-embryonic development (Ketoh, Koumaglo, Glitho and Huignard, 2006; Udo et al., 2011).

Untreated cowpea seeds suffer great damage due to $C$. maculatus infestation, whereas negligible or no damage/ weight loss were recorded in cowpea seeds that were treated with the $P$. guineense leaves powders and extract. Beetle Perforation Index (BPI) value lower than 50 is an index of positive protectant effect while BPI greater than 50 is an index of negative protectability. The reduction of damage observed in this study is the consequence of the higher adult mortality, antifeedant, oviposition deterrence, ovicidal, larvicidal and reproduction inhibitory properties of P. guineense (Isman, 2006; Lale and Abdulrahman, 1999; Manikanta and Dokuparthi, 2014). The efficacy of seed extract obtained was in consonance with the findings of Eziah, Buxton and Owusu (2013) who reported that methanol extracts of Zanthoxylum zanthoxyloides and Securidaca longepedunculata roots significantly reduced the damage caused by Prostephanus truncatus and Tribolium castaneum on maize grains.

Insecticidal activity of plant materials depends on the abundance of active compounds of the plant material. The major bioactive constituents isolated from the methanol leaves and seeds extracts of $P$. guineense were similar to those reported in P. guineense obtained from Cameroun, South Eastern and South Western Nigeria (Oben, McConchi, Phan-Thien and Ntonifor, 2015; Ojinnaka, Ubbor, Okudu and Uga, 2016; Owolabi, Lawal, Ogunwande, Hauser and Setzer, 2013; Oyedeji, Adeniyi, Ajayi and König, 2005; Tchoumgougnang et al., 2009); however, there was a slightly difference in the concentrations of the major bioactive constituents found. The observed compositional variability in the bioactive chemical composition might be due to several factors such as environmental and climatic, soil fertility variations, genetic makeup of the plant, phenological state of the plant, different chemotypes and solvents used for extraction (Isman and Machial, 2006; Perry et al., 1999). The screening of this plant species revealed the presence of tannins, saponins, alkaloids, flavonoids and cardiac glycosides. It was reported that $P$. guineense contains bioactive ingredients such as neurotoxic piperamides and lignans, alpha-pinene, limonene, Linalool, piperine and chavicine, which are insecticidal including piperidine and alkaloids as the major active components in P. guineense seeds (Golob, Mwumbola and Mbhango Ngulube, 1999; Lale, 1995; Scott et al., 2004; Scott, Gagnon, Lesage, Philoge and Arnason, 2005). The plant phytochemicals exerted their action on the physiological, biochemical and enzymatic process of the insects.

Many studies have identified $\beta$-Phellandrene, eugenol, limonene, linalool, $\alpha$-pinene and $\beta$-pinene as components of plant essential oils and also tested fumigant and 
contract toxicities of phytochemicals from plant (Beyrouthy et al., 2011; Demirci, Özek and Baser, 2000; Nenaah, 2014; Phillips and Appel, 2010; Phillips, Appel and Sims, 2010; Yeom et al., 2015). However, there are scarce reports on their pesticidal potential because they are not commercialised (Szolyga, Gnilka, Szczepanik and Szumny, 2014).

\section{Conclusion}

This study has further demonstrated that $P$. guineense leaf and seed possess phytochemicals that confer on it significant insecticidal value as a potential stored seeds protectant, having the capacity to evoke high mortality within $24 \mathrm{~h}$ and greatly suppressed oviposition, progeny development and seed damage. Its adoption as suitable alternative to synthetic insecticides as seed protectant should be encouraged amongst resource-poor farmers as a means of ensuring a steady supply of quality food, since it has traditionally been used as a spice and medicine and has been proven safe for humans.

\section{Abbreviations}

ANOVA: Analysis of variance; IR: Progeny inhibition; BPI: Beetle Perforation Index; GC-MS: Gas chromatography-mass spectrometry; IITA: International Institute for Tropical Agriculture; +: Positive; -: Negative

\section{Acknowledgements}

The authors thank Dr. Obembe of the department of Plant Science and Technology, Adekunle Ajasin University Akungba Akoko, Nigeria, for the authentication of botanicals used. We appreciate staff of Insect Chemical Ecology Laboratory, Institute of Bioresources and Sustainable Development, Takyelpat, Imphal, 795001, Manipur, India, for their assistance during the GCMC analysis.

\section{Authors' contributions}

This research work was carried out in collaboration amongst all authors. KDI conceived and designed the study and contributed to the data analysis and manuscript reviewing; $\mathrm{KDI}, \mathrm{AO}$ and LCN collected the data on insect bioassay; JMA conducted the GC-MS analysis and reference search and contributed to the manuscript draft. All authors read and approved the final manuscript.

\section{Funding}

The research work was self-funded.

\section{Availability of data and materials}

Sharing of data is not applicable.

\section{Ethics approval and consent to participate}

Not applicable

\section{Consent for publication}

Not applicable.

\section{Competing interests}

The authors declare that they have no competing interests.

\section{Author details}

${ }^{1}$ Applied Entomology Unit, Department of Biology, School of Science, Federal University of Technology, PMB 704, Akure, Ondo State, Nigeria. ${ }^{2}$ Department of Crop, Soil and Pest Management Technology, Rufus Giwa Polytechnic, P. M. B. 1019, Owo, Ondo State, Nigeria. Insect Chemical Ecology Laboratory, Institute of Bioresources and Sustainable Development, Takyelpat, Imphal, Manipur 795001, India. ${ }^{4}$ Department of Crop and Soil Science, Faculty of Agriculture, University of Port Harcourt, Port Harcourt,
Rivers State, Nigeria. ${ }^{5}$ Department of Animal and Environmental Biology, Faculty of Science, Adekunle Ajasin University, Akungba Akoko, Ondo State, Nigeria.

Received: 10 April 2020 Accepted: 18 September 2020

Published online: 06 October 2020

\section{References}

Abbott, W. S. (1925). A method of computing the electiveness of an insecticide. Journal of Economic Entomology, 18, 265-267.

Abdullahi, Y. M., \& Muhammad, S. (2004). Assessment of the toxic potentials of some plant powders on survival and development of Callosobrochus maculatus. African Journal of Biotechnology, 3, 50-62.

Adams, R. (2007). Identification of essential oil components by gas chromatography/ mass spectrometry. Chicago, IL, USA: Allured Publishing Co.

Adedire, C. O., Obembe, O. O., Akinkurolele, R. O., \& Oduleye, O. (2011). Response of Callosobruchus maculatus (Coleoptera: Chysomelidae: Bruchidae) to extracts of cashew kernels. Journal of Plant Diseases and Protection, $118(2), 75-79$.

Adesina, J. M. (2013). Insecticidal potential of Momordicacharantia (L.) leaves powder against maize weevil Sitophilus zeamais (mots.) (Coleoptera: Curculionidae) infestation. International Journal of Bioscience, 3(1), 28-34.

Adesina, J. M., Jose, A. R., Rajashekar, Y., \& Afolabi, L. A. (2015). EntomoToxicity of Xylopia aethiopica and Aframomum melegueta in suppressing oviposition and adult emergence of Callasobruchus maculatus (Fabricus) (Coleoptera: Chrysomelidae) infesting stored cowpea seeds. Jordan Journal of Biological Science, 8(4), 263-268.

Adesina, J. M., \& Ofuya, T. I. (2015). Oviposition deterrent and egg hatchability suppression of Secamone afzelii (Schult) K. Schum leaf extract on Callosobruchus maculatus (Fabricius) (Coleoptera: Chrysomelidae). Jordan Journal of Biological Science, 2015, 8(2), 95-100.

Arannilewa, S. T., Ekrakene, T., \& Akinneye, J. O. (2006). Laboratory evaluation of four medicinal plants as protectants against the maize weevil Sitophilus zeamais. African Journal of Biotechnology, 5(21), 2032-2036.

Ashamo, M. O., \& Akinnawonu, O. (2012). Insecticidal efficacy of some plant powders and extracts against the Angoumois moth, Sitotroga cerealella (Olivier) [Lepidoptera: Gelechiidae]. Archives Phytopathology and Crop Protection, 45(9), 1051-1058.

Beyrouthy, M. E., Arnold-Apostolides, N., Labaki, M., Cazier, F., Najm, S., \& Abouaïs, A. (2011). Chemical composition of the essential oil of the Artemisia arborescens L. growing wild in Lebanon. Lebanese Science Journal, 12, 71-78.

Casswell, G. H. (1981). Damage to stored cowpeas in the northern part of Nigeria. Samaru Journal of Agricultural Research, 1, 154-158.

Dalziel, J. M. (1955). The useful plants of west tropical Africa. In 2nd printing. London: Crown Agents.

Demirci, B., Özek, T., \& Baser, K. H. C. (2000). Chemical composition of Santolina chamaecyparissus L. essential oil. Journal of Essential Oil Research, 12, 625-627.

Enslee, E. C., \& Riddiford, L. M. (1977). Morphological effects of juvenile hormone mimics on embryonic development in the bug Pyrrhocoris apterus. Wilhelm Roux's Archive of Developmental Biology, 181, 163-181.

Eziah, V. Y., Buxton, T., \& Owusu, O. E. (2013). Bioefficacy of Zanthoxylum xanthoxyloides and Securidaca longependuncata against Prostephanus truncatus (horn) and Tribolium castaneum (Herbst). Journal of Biopesticides, 6(1), 54-62.

Fasakin, E. A., \& Aberejo, B. A. (2002). Effect of some pulverized plant materials on the developmental stages of fish beetle, Dermestes maculatus Degeer in smoked cat fish (Clarias gariepinus) during storage. Bioresource Technology, 85 , 173-177.

Fatope, M. O., Mann, A., \& Takeda, Y. (1995). Cowpea weevil bioassay: A simple prescreen for plants with grain protectant effects. Journal of Pest Management, 41, 44-86.

Golob, O. J., Mwumbola, V., \& Mbhango Ngulube, F. (1999). The use of locally available materials as protectants of maize grains against insects infestation during storage in Malawi. Journal of Stored Product Research, 18, 67-74.

Harborne, J. B. (1973). Phytochemical methods: A guide to modern technique of plant analysis. London: Charpman and Hall.

Idoko, J. E., \& Adesin, J. M. (2012). Evaluation of the powder of Piper guineense and pirimiphos- Methly F for the control of cowpea beetle Callosobruchus maculatus (F.). Journal of Agricultural Technology, 8(4), 1365-1374.

IITA International Institute for Tropical Agriculture (1995). Plant health management division, (p. 43). Annual Report. 
lleke, K. D. (2014). Cheese wood, Alstonia boonei De wild a botanical entomocides for the management of maize weevil, Sitophilus zeamais (Motschulsky) (Coleoptera: Curculionidae). Octa Journal of Bioscience, 2(2), 64-68.

lleke, K. D., Odeyemi, O. O., \& Ashamo, M. O. (2013). Response of cowpea bruchid, Callosobruchus maculatus (Fabr.) [Coleoptera: Chrysomelidae] to cheese wood, Alstoniaboonei de wild stem bark oil extracted with different solvents. Archives of Phytopathology and Plant Protection, 46(11), 1357-1370.

Islam, R., Khan, R. I., Al-Reza, S. M., Jeong, Y. T., Song, C. H., \& Khalequzzaman, M. (2009). Chemical composition and insecticidal properties of Cinnamomum aromaticum (Nees) essential oil against the stored product beetle Callosobruchus maculatus (F). Journal of Science, Food and Agriculture, 89(7), $1241-1246$

Isman, M. B. (2006). Botanical insecticides, deterrents, and repellents in modern agriculture and an increasingly regulated world. Annual Review of Entomology, 51, 45-66.

Isman, M. B., \& Machial, C. M. (2006). Pesticides based on plant essential oils from traditional practice to commercialization. In: Rai, Carpinella (Eds.), naturally occurring bioactive compounds. Elsevier publishing co. pp. 29-44.

Ivbijaro, M. F., \& Agbaje, M. (1986). Insecticidal activities of $P$. guineense and Capsicum spp. on the cowpea bruchid, Callosobruchus maculatus. Insect Science and Its Application, 7(4), 521-524.

Ketoh, G. K., Koumaglo, H. K., Glitho, I. A., \& Huignard, J. (2006). Comparative effects of Cymbopogon schoenanthus essential oil and piperotone on Callosobruchus maculatus development. Fitoterapia, 77, 506-510.

Koehler, P. G. (2003). Biopesticides Data sheet volume 2. Entomology and nematology Dept, cooperative extension service, Institute of Food and Agricultural Science, University of Florida, Gainesville. 2003, 326p.

Lale, N. E. S. (1995). An overview of the use of plant products in the management of stored product Coleoptera in the tropics. Post-Harvest News Information, 6, 69-75.

Lale, N. E. S. (2002). Stored product entomology and acarology in Tropical Africa. Mole publications (Nig) Itd, (pp. 4-5). Nigeria: Maiduguri.

Lale, N. E. S., \& Abdulrahman, H. T. (1999). Evaluation of neem (Azadirachta indica a. Juss) seed oil obtained by different methods and neem powder for the management of Callosobruchus maculatus (F.) (Coleoptera: Bruchidae) in stored cowpea. Journal of Stored Product Research, 35, 135-143.

Larochelle, C., Katungi, E., \& Cheng, Z. (2016). Household consumption and demand for bean in Uganda: Determinants and implications for nutrition security. In Invited paper presented at the $5^{\text {th }}$ international conference of the African Association of Agricultural Economists, September 23-26, 2016. Addis Ababa: Ethiopia.

Manikanta, P., \& Dokuparthi, S. S. K. (2014). A review on role of Azadirachta indica a. Juss as a biopesticide. Internatioal Journal of Universal Pharmaceutical Bioscience, 3, 2319-8141.

Nenaah, G. E. (2014). Chemical composition, toxicity and growth inhibitory activities of essential oils of three Achillea species and their nanoemulsions against Tribolium castaneum (Herbst). Industrial Crops and Products, 53, 252-260.

Nwosu, L. C. (2019). Assessment of bone charcoal dusts of six species of mammal for the postharvest control of Callosobruchus maculatus Fabricius (Coleoptera: Chrysomelidae) infestations of cowpea seeds: Can the charcoal dust affect seed viability in laboratory and in field? Food Quality and Safety, 3, 279-287.

Oben, E. O., McConchi, R., Phan-Thien, K., \& Ntonifor, N. N. (2015). Essential oil composition of different fractions of Piper quineense Schumach and Thonn from Cameroon using gas chromatography-mass spectrometry and their insecticidal effect on Sitophilus oryzae (L.). African Journal of Biotechnology, 14(36), 2662-2671.

Odeyemi, O. O., \& Daramola, A. M. (2000). Storage practices in the tropics, (p. 235). Nigeria: Dave Collins Publication.

Ofuya, T. I., \& Dawodu, E. O. (2002). Aspects of insecticidal action of Piper guineese Schum and Thonn fruit powder against Callosobrunchus maculatus (F) (Coleoptera: Bruchidae). Nigerian Journal of Entomology, 19, 40-50.

Ogunwolu, E. O., Igoři, J. O., \& Longs, N. N. (1988). Reduction in reproductive fitness of Callosobruchus maculatus F. exposed to Zanthoxylum zanthoxyloides (lam.) Waterm. Journal of Herbs, Spices and Medicinal Plants, 6(1), 19-27.

Ojinnaka, M. C., Ubbor, S. C., Okudu, H. O., \& Uga, U. (2016). Volatile compound analysis of the leaves and seeds of Piper guineense using gas chromatographymass spectrometry (GC-MS). African Journal of Food Science, 10(11), 327-332.

Oparaeke, A. M., \& Bunmi, J. O. (2006). Bioactivity of two powdered spices Piper guineense Thonn and Schum and Xylopia aethiopica (Dunal) a. Richard as homemade insecticides against Callosobruchus subinnotatus (pic.) on stored Bambarra groundnut. Agricultura Tropica et Subtropica, 39(2), 132-135.

Owolabi, M. S., Lawal, O. A., Ogunwande, A. I., Hauser, R. M., \& Setzer, W. N. (2013). Aroma chemical composition of Piper quineense Schumach. And Thonn. From Lagos, Nigeria: A new chemotype. American Journal of Essential Oils and Natural Product, 1(1), 37-40.

Oyedeji, O. A., Adeniyi, B. A., Ajayi, O., \& König, W. A. (2005). Essential oil composition of Piper guineense and its antimicrobial activity; another chemotype from Nigeria. Phytotherapy Research, 19, 362-364.

Perry, N., Anderson, R., Brennan, N., Douglas, M., Heaney, A., McGrimpsey, J., \& Smallfield, B. (1999). Essential oil from Dalmation sage (Salvia officinalis L.), variations among individuals, plant parts, seasons and sites. Journal of Agriculture and Food Chemistry, 47, 2048-2054.

Phillips, A. K., \& Appel, A. G. (2010). Fumigant toxicity of essential oils to the German cockroach (Dictyoptera: Blattellidae). Journal of Economic Entomology, 103, 781-790

Phillips, A. K., Appel, A. G., \& Sims, S. R. (2010). Topical toxicity of essential oils to the German cockroach (Dictyoptera: Blattellidae). Journal of Economic Entomology, 103, 448-459.

Prashant, T., Bimlesh, K., Mandeep, K., Gurpreet, K., \& Harleen, K. (2011). Phytochemical screening and extraction: A review. International of Pharmaceutical Sciences, 1(1), 23-28.

Rajkumar, S., \& Jebanesan A. (2004). Mosquitocidal activities of octacosane from Moschosma polystachyum Linn. (Lamiaceae). Journal of Ethnopharmacology,90(1): 87-89.

Rouanet, G. (1992). Maize. The Tropical Agriculturist, (p. 102). London: CTA, Macmillian. Scott, I. M., Gagnon, N., Lesage, L., Philoge, B. J. R., \& Arnason, T. (2005). Efficacy of botanical insecticides from Piper species (Piperaceae) extracts for control of European chafer (Coleoptera: Scarabaeidae). Journal of Economic Entomology, 98, 845-855.

Scott, I. M., Jensen, H., Nicol, R., Lesage, L., Bradbury, R., Sánchez-Vindas, P., ... Philogène B. J. R. (2004). Efficacy of Piper (Piperaceae) extracts for control of common home and garden insect pests. Journal of Economic Entomology, 97(4), 1390-1403.

Sofowora, A. (1993). Medicinal Plants and Traditional Medicine in Africa, 3rd ed. P. 195-238.

SPSS (2017). Statistical package for social sciences, 2017. Chicago, IL: SPSS, Inc.

Su, C. H. F. (1977). Insecticidal properties of black pepper to rice weevils. Journal of Economic Entomology, 70, 18-21.

Sukhthankar, J. H., Kumar, H., Godinho, M. H. S., \& Kumar, A. (2014). Larvicidal activity of methanolic leaf extracts of plant, Chromolaena odorata $\mathrm{L}$. (Asteraceae) against vector mosquitoes. International Journal of Mosquito Research, 1(3), 33-38.

Szolyga, B., Gnilka, R., Szczepanik, M., \& Szumny, A. (2014). Chemical composition and insecticidal activity of Thuja occidentalis and Tanacetum vulgare essential oils against larvae of the lesser mealworm, Alphitobius diaperinus. Entomologia Experimentalis et Applicata, 151, 1-10.

Tapondjoun, L. A., Alder, A., Bonda, H., \& Fontem, D. A. (2002). Efficacy of powder and oil from Chenpodium ambrosioides leaves as post-harvest grain protectants against six stored products beetles. Journal of Stored Products Research, 38, 395-402.

Tchoumgougnang, F., Jazet Dongmo, P. M., Sameza, M. L., Fombotioh, N., Wouatsa Nangue, A. V., Amvam Zollo, P. H., \& Menut, C. (2009). Comparative essential oils composition and insecticidal effect of different tissues of Piper capense L., Piper guineense schum.Et Thonn., Piper nigrum L. and Piper umbellatum L. grown in Cameroon. African Journal of Biotechnology, 8(3), 424-431.

Trease, G. E., \& Evans, W. C. (1998). Pharmacognosy. Brailliar Tiridel, Canada: Macmillan publishers.

Udo, I. O., Ekanem, M. S., \& Inyang, E. U. (2011). Laboratory evaluation of west African black pepper (Piper guineense) seed powder against maize weevil (Sitophilus zeamais mots.). Munis Entomology and Zoology, 6(2), 1003-1007.

Yeom, H., Jung, C., Kang, J., Kim, J., Lee, J., Kim, D., ... Park, I. (2015). Insecticidal and acetylcholine esterase inhibition activity of Asteraceae plant essential oils and their constituents against adults of the German cockroach (Blattella germanica). Journal of Agricultural and Food Chemistry, 63, 2241-2248.

Zabri, H., Kabran, G. R., Kodjo, C., \& Trabi, F. (2009). Purification and characterization of a coumarin in methanolic leaf extracts of Secamone afzelii (Asclepiedacea) from Côte d'Ivoire. Journal of Animal and Plant Sciences, 3(2): 182-185.

\section{Publisher's Note}

Springer Nature remains neutral with regard to jurisdictional claims in published maps and institutional affiliations. 